\title{
O IMPASSE TRÁGICO E A VIA CÔMICA NA ÉTICA DA PSICANÁLISE
}

Laura Lustosa Rubião

Psicanalista, mestre em lógica e filosofia da ciência pela Universidade de Campinas/Unicamp
RESUMO: Trata-se de uma análise do comentário feito por Lacan sobre a peça Antígona, de Sófocles, no seminário A Ética da Psicanálise, com o intuito de se indagar sobre o alcance e as limitações da designação trágica do desejo. Em seguida, procura-se resgatar o interesse lacaniano pela comédia antiga — por meio do exame de algumas passagens do teatro de Aristófanes - explorando-se as contribuições dessa outra via para a perspectiva ética da psicanálise.

Palavras-chave: Teatro antigo, psicanálise, ética.

ABSTRACT: The tragic deadlock and the comic perspective in the psychoanalysis ethics It is an analysis of Lacan's commentary on Sophocles' play Antigone presented at his seminar on The Ethics of Psychoanalysis, aiming at inquiring about the reach and limits of the tragic designation of desire. Subsequently, we try to ransom the Lacanian interest in the Ancient Comedy by examining some passages of the Aristophanes' theater, exploring the contributions of this perspective to the ethics of psychoanalysis.

Keywords: Ancient theater, psychoanalysis, ethics.

$\mathrm{E}$ ntre a reverência e o enfado, o fascínio e o tédio: eis onde é possível situar, de acordo com Kathrin Rosenfield, o olhar moderno sobre a tragédia antiga (ROSENFIELD, 2000). Não é preciso avançar muito no exame de seu ensaio para que se possa notar o quanto o fastio é preponderante em relação ao entusiasmo, à surpresa, ao suspense.

Esse olhar, excessivamente adestrado à lógica dos conceitos e às construções racionalizantes, reservaria um enquadre ordinário ao drama trágico, privando-lhe de toda virulência e originalidade. Tal fastio é visto como efeito do ofuscamento daquilo que de mais inquietante nos lega a 
tragédia ática: uma lógica implacável, um paradoxo insolúvel. Este o preço a ser pago, segundo a crítica da referida autora, quando a interpretação "fixa a atenção sobre problemas isolados e abstratos que transformam a ação trágica em teses filosóficas” (Idem, p.17). Essa constatação não deixa de encontrar ressonâncias na tese nietzschiana, segundo a qual o impulso concedido à dialética socrática pelo pensamento filosófico de Platão — da qual é tributária boa parte da tradição filosófica ocidental — teria coincidido com o ocaso da tragédia (NIETZSCHE, 1872/1992)

A autora toma como referência para sua análise a Antígona, de Sófocles, um dos dramas trágicos mais revisitados pela modernidade. Admira-se com a monotonia com que vemos reduzir-se essa trama ao famoso refrão do conflito entre a lei do sangue (da família) e a lei do Estado, representada por Creonte.

Seguramente, a leitura hegeliana da tragédia é o eixo central dessa argumentação.

A tragédia grega, tal como se configurou ao longo do quinto século antes de Cristo, teria servido, de acordo com George Steiner, como um "terreno de prova e validação para os pontos fundamentais do historicismo de Hegel" (STEINER, 1995, p.38), sustentado pela noção central do progresso da consciência por meio do conflito.

É, portanto, nos limites de uma perspectiva teleológica que Hegel irá conceber o conflito trágico. Trata-se, com efeito, de circunscrever os preceitos de uma ética - que se apresenta sempre em estreita subordinação aos princípios da vida coletiva - nos limites da tensão necessária entre os interesses particulares e os do Estado. Sendo o conflito, aos olhos de Hegel, essencialmente criador e restaurador, o alvo visado no horizonte traduz-se num momento de síntese, em que se assiste à superação das antinomias e à configuração de uma totalidade dialética (STEINER, 1995).

O ethos trágico, tal como formulado por Hegel em sua leitura da peça de Sófocles, reconhece no conflito levado ao extremo (ou seja, nas posições rígidas tanto de Antígona como de Creonte) uma maneira de demonstrar como o processo de individuação esbarra em um limite necessário, inevitável, representado pela morte, mas que traz, na sua contrapartida dialética, a possibilidade do encontro da substância ética absoluta e universal.

O livro de Jacques Taminiaux, Le théatre des philosophes, merece ser aqui evocado, na medida que pode ser articulado, parcialmente, ao que denuncia Rosenfield em seu artigo. O autor sublinha o quanto os filósofos, representantes do idealismo alemão, imprimiram um tom metafísico e ontológico às suas leituras referentes à tragédia, tom este que os distanciou, em larga medida, da visão clássica de Aristóteles — que enfatiza os efeitos da ação trágica propriamente dita. Uma das perguntas centrais por ele formuladas ao longo de suas 
análises e que pode ser endereçada tanto a Hegel, Schiller, Schelling e a outros (à exceção de Hölderlin) seria a seguinte: o que teria restado da hybris trágica, reveladora de um excesso em que se lançam, irremediavelmente, os heróis? (TAMINIAUX, 1995, p.106 e 255)

Feitas essas considerações preliminares, gostaríamos de trazer ao âmbito desse debate, o comentário sobre Antígona proferido por Lacan, por ocasião da apresentação de seu seminário sobre a Ética da Psicanálise (LACAN, 1960/ 1991).

Parece-nos plausível situar a leitura lacaniana do teatro trágico antigo, tal como se pronuncia no Seminário 7, bem mais ao lado do fascínio, no sentido positivo que confere Rosenfield a esse termo, uma vez que o opõe ao tédio e à monotonia. Lacan salienta a posição paradoxal de sua heroína e situa aí, justamente nessa condição paradoxal, a razão do seu poder de fascínio:

"Pois bem, sabemos que para além dos diálogos, para além da família e da pátria, para além dos desenvolvimentos moralizadores, é ela que nos fascina, em seu brilho insuportável, naquilo que ela tem que nos retém e, ao mesmo tempo, nos interdita, no sentido em que isso nos intimida, no que ela tem de desnorteante — essa vítima terrivelmente voluntária.” (LACAN, 1960/1991, p.300)

Se Antígona segue os desígnios de sua áte, é somente para transformá-los em um ato de vontade tributário de sua singularidade e não recoberto pelas regras de qualquer rede discursiva (simbólica) que lhe possa servir de referência. Assim, a personagem trágica, na leitura lacaniana, exprime a condição de desamparo e solidão do sujeito que, por estrutura, define-se como sem recurso, sem apelo possível ao campo do Outro (LACAN, 1960/1991). Estamos a uma considerável distância da trama reconciliadora de Hegel, bem como do elevado gesto moral da heroína de Goethe.

Se, por um lado, o olhar da psicanálise sobre os efeitos da tragédia contempla a dimensão do conflito como necessário e indissolúvel, por outro - e esse será o eixo principal de nossa argumentação — a visão trágica do desejo não deixa de acarretar um impasse teórico-clínico, cujas conseqüências gostaríamos de abordar a partir de um exame sobre as contribuições advindas da perspectiva cômica. Nosso percurso será sinalizado por uma questão de fundo, que cumpre antecipar desde já: em que medida os estudos sobre a comédia, em particular os referentes à comédia antiga, podem lançar alguma luz sobre o debate relativo à Ética em psicanálise, uma vez contrapostos ao modelo trágico em que ele está apoiado nos anos 1960 ?

O fio de nossa argumentação conduzir-nos-á a uma apreensão da via cômica, no mesmo registro reservado ao modelo trágico, ou seja, aquele que 
propõe uma saída Ética, sem abrir mão do paradoxo fundamental que está na base conceitual do desejo para a psicanálise.

Para se compreender como a ética da psicanálise pôde ser articulada à tragédia e por que a Antígona de Sófocles ocupou um lugar privilegiado nessa conexão, é preciso lançar mão de alguns instrumentos teóricos que serviram de apoio para a confecção do Seminário VII de Lacan. Esse foi um momento fecundo do pensamento do autor, propício a reformulações de certos pressupostos conceituais que, até então, guiavam o movimento de retorno a Freud, por ele empreendido.

A peculiaridade desse retorno deu-se a partir da aliança teórica estabelecida entre o corpo teórico da psicanálise e os princípios da lingüística estrutural, quando, então, tornou-se possível soldar o vínculo entre inconsciente e linguagem, na contracorrente das visões naturalistas, empiristas ou essencialistas, capazes de apreender a mensagem inconsciente como referida a algum sentido anterior ou exterior à matéria de que ela é feita. No ato da dissociação da prática da psicanálise de um projeto hermenêutico, Lacan anunciava, nos primórdios de seu ensinamento, a morte da coisa pela inscrição do símbolo. Assim se dispunham as vias de acesso ao inconsciente que não conhece outra realidade senão aquela da palavra e da materialidade significante.

O enquadre teórico em que se desenrola a discussão sobre a Ética distingue-se do anterior, na medida que são incluídos aí alguns elementos novos que requerem um redimensionamento da relação entre o inconsciente e a rede de linguagem.

Um dos conceitos-chave que está na base dessa mudança de perspectiva e ao qual subordina-se todo o debate em torno da ética do desejo inconsciente, é o da Coisa (das Ding). Essa noção encontra-se desenvolvida em um texto freudiano de 1895 intitulado Projeto para uma psicologia científica.

Ali, a argumentação freudiana pretende fornecer as bases para o funcionamento dos processos psíquicos que se afirmam a partir da instauração de uma memória do desejo. O que é preciso ressaltar, para o nosso interesse ainda que a necessidade de brevidade sacrifique a complexidade deste texto - é a extrema dependência do sujeito humano ao que se denominou o complexo do outro: Nebenmensch (FREUD, 1895/1976, p.438). Esse outro semelhante é sua única fonte auxiliar e, ao mesmo tempo, o primeiro objeto hostil; responde aos diversos apelos, por meio da fala e da interpretação e não apenas como um dispositivo de suspensão das necessidades. O estado de desamparo (Hilflosigkeit), que está na base do apelo dirigido ao outro, Freud o especifica como sendo a "fonte de todos os motivos morais" (FREUD, 1895/ 1976, p.421). Quando esse aparelho, movido pela reativação das experiências 
de prazer, obstinar-se no reconhecimento desse outro que lhe propiciara a primeira experiência de satisfação, ele deparar-se-ia com uma parte do complexo, que cedeu de maneira favorável ao processo mnêmico de reconhecimento e, com outra, que se apresenta como "uma estrutura que persiste coerente como uma coisa” (FREUD, 1895/1976, p.438).

A coisa, tal como tematizada por Freud, é a parte inassimilável e incomparável do complexo do outro. O desamparo primordial do sujeito só pode condicionar a moralidade porque o outro é um ser falante, que opera no registro do equívoco e da ambigüidade. O desamparo a que nos remete Freud deve ser lido, portanto, como um distintivo do humano, caso contrário, marcaria um dado de pura necessidade a ser suspenso por uma provisão material qualquer e em nada poderia contribuir para uma formulação ética (moral) acerca do sujeito. É, precisamente no ponto de desajuste entre a demanda e o que lhe é oferecido como resposta que se instala o campo de das Ding e do desejo, para além da satisfação das necessidades. Esse conceito é entendido por Lacan como um “fora-do-significado” (LACAN, 1960/1991, p.71) em torno do qual circulam as possibilidades de significação.

É assim, portanto, que nos moldes conceituais do seminário sobre a Ética, a linguagem assume um valor de corte e funda o domínio de das Ding, como um ponto de opacidade, que está no centro da estrutura sem que, no entanto, seja capturado nela.

Antígona é lida à luz desse limite entre o significante e a coisa, entre o que é passível de um desdobramento simbólico ou de inscrição no plano discursivo e o que faz barreira a essa possibilidade.

Bem antes de tornar público seu comentário sobre a peça de Sófocles, o autor deixara claro o modo pelo qual delineava-se seu interesse pela tragédia antiga:

“a tragédia representou a relação do homem com a fala, uma relação tomada em sua fatalidade - uma fatalidade conflitante - posto que a cadeia que liga o homem à lei significante não é a mesma no nível da família (áte) e no nível da

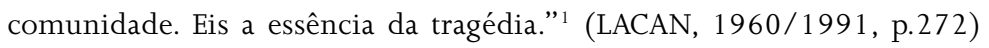

\footnotetext{
${ }^{1}$ Vê-se, claramente, que ao propor uma essência da tragédia, Lacan já se pautava pela referência à Antígona, que, pelas peculiaridades da trama, melhor servia para acolher suas teses. É muito improvável que essa definição possa estender-se ao gênero trágico em geral. Cf. LACAN, 1958/ 1999, p.272.
} 
A noção de fatalidade tomada em sua relação com o conflito e com o aspecto da divisão subjetiva torna-se preciosa quando se quer pensar nos efeitos da tragédia antiga, pois problematiza a idéia de submissão e passividade dedutível de todo fatalismo. O herói trágico não é aquele que cumpre cegamente os desígnios de uma ordem divina que o antecede. É da tensão permanente e insolúvel entre as potencialidades humanas — nitidamente postas em relevo pela constituição da cidade grega e pelo avanço das práticas políticas, jurídicas e científicas - e o universo do mito, que nasce a originalidade do conflito trágico (VERNANT \& VIDAL-NAQUET, 1988, p.22).

É importante destacar, sobretudo, que, para Lacan, essa fatalidade é constitutiva e estrutural no ser falante, ou seja, que o desejo, por ser desejo do Outro, apresenta-se, certamente, sob a forma de um legado, mas do qual o sujeito deve apropriar-se. Só assim o gesto radical de Antígona - enterrar o irmão contra o édito de Creonte, rei de Tebas, sob pena de perder a vida pode ser visto como um gesto único, que se impõe como uma exceção a toda exigência de coerência e explicação lógicas. Um gesto que deve assegurar-se de sua própria estranheza, pois não se mostra inteiramente solidário nem da herança sanguinária da saga dos Labdácidas (áte divina), nem tampouco da justiça distributiva encarnada pela lei da cidade. Lacan concentra seu argumento na passagem da peça em que Antígona é intimada por Creonte a falar de sua transgressão, e propõe a seguinte tradução: "pois de maneira nenhuma foi Zeus quem proclamou essas coisas para mim” (LACAN, 1960/1991, p.336). Dessa forma, coloca em destaque a marca da "individualidade absoluta" (Idem) digna de sua heroína, rigorosamente situada no deserto de seu desamparo fundamental. Se ela é levada a cumprir a sua áte, a atrelar-se ao fio criminoso que perpassara todo seu legado ancestral, isso se dá apenas no momento de uma apropriação em que se desenha uma resposta singular. Portanto, um gesto tão estranho quanto a justificativa que lhe atribui a personagem ao afirmar que não teria feito o mesmo por um esposo ou filho mortos, pois um novo matrimônio reabilitaria sua condição de esposa ou de mãe, enquanto que, estando já mortos seus pais, o irmão seria insubstituível (SÓFOCLES, 1999, p.58-59).

Áte é um termo grego antigo, presente em Homero, em geral designando "uma conduta imprudente e inexplicável (...) sem qualquer referência explícita à intervenção divina” (DOODS, 1988, p.11), espécie de loucura ou obscurecimento do estado normal da consciência. Quase sempre traduzido por desgraça, ruína, ou simplesmente tragédia, como propõe Jean Bollack, é um termo recorrente nos textos trágicos.

Lacan permite-se recusar todas essas traduções, sem que possa propor qualquer outra de forma decisiva: “Essa é uma palavra insubstituível. Ela designa o 
limite que a vida humana não poderia transpor por muito tempo"2 (LACAN, 1960/1991, p.318). Uma vez transposto tal limite — e esse é um movimento que se impõe à personagem -, sobrevém o caráter, a um só tempo, enigmático e desumano, da heroína lacaniana. Desumano, esclarece o autor, no sentido de não civilizado, de cru (LACAN, 1960/1991).

Essa áte, tal como compreendida por Lacan, ou seja, como uma zona fronteiriça, cuja ultrapassagem erradica toda a possibilidade de manutenção da vida humana, constitui, a seus olhos, aquilo que, para Antígona, tratar-se-ia de transpor, ainda que não por muito tempo. Se ela é desumana, não é propriamente por encarnar a história que guarda a marca do incesto, mas antes por inscrever seu desejo num ponto sem ancoragem simbólica no Outro, retratando, dessa forma, o cerne mesmo do que vem a ser o desejo para Lacan, nesse momento de seu ensino.

É, sobretudo, o efeito de "curto-circuito" dos princípios da ética tradicional (Aristóteles), promovido pela ética trágica, que será realçado no comentário de Lacan: "é porque o homem toma o mal pelo bem, porque alguma coisa para-além dos limites da áte tornou-se para Antígona seu próprio bem, um bem que não é o de todos, que ela se dirige pros atan"3 (LACAN, 1960/ 1991, p.328). Um bem que não é o de todos é aquele que não está pautado por qualquer critério de universalização, que não se define pela supremacia de qualquer essência. É justamente em relação a esse ponto que se demarcam, segundo o autor, as posições dissimétricas de Antígona e Creonte. Enquanto a primeira apresenta-se desprovida de qualquer referência que lhe possa assegurar uma orientação entre o bem e o mal, o segundo, por sua vez, encontrase bem orientado pela ordem de uma justiça eqüitativa capaz de prescrever a impossibilidade de "se tornar parente (amigo) de um homem que quer mal à minha terra” (SÓFOCLES, 1999, p.22). Munido de uma razão política, que afinal não sustenta por muito tempo o discernimento do seu gesto, Creonte acredita poder firmar sua decisão fora de qualquer contradição ou paradoxo.

De fato, Antígona não está aí para demandar, lutar ou argumentar propriamente em favor de nada. Coloca-se, de saída, como uma morta entre os vivos

\footnotetext{
${ }^{2}$ É oportuno notar que, em 1957, em seu artigo De uma questão preliminar a todo tratamento possível da psicose, Lacan adota uma expressão semelhante ao mencionar certos "princípios permanentes das organizaçôes coletivas, fora das quais a vida humana não parece manter-se por muito tempo". Interessa-nos em especial a articulação entre a via trágica do desejo e esse ponto fora das organizações coletivas, ou fora da possibilidade do laço social, tão acentuado no caso das psicoses (Cf. LACAN, 1995, p.554).

${ }^{3}$ Sobre o termo atan: trata-se do acusativo singular regido pela preposição pros, o que se traduz como: Antígona vai em direção à sua áte.
} 
(SÓFOCLES, 1991, p.41), para quem o fim já está consumado, como algo necessário e definitivo.

A questão da morte, proposta por Lacan, comporta vários desdobramentos no fio da discussão sobre a tragédia. Ainda que não possamos, nos limites reservados a essa reflexão, abarcar todas as suas peculiaridades, alguns pontos merecem destaque.

Há, a princípio, o recurso a uma passagem da obra de Sade, que põe em relevo a existência da segunda morte e advoga contra a naturalidade do crime. ${ }^{4}$ As honras fúnebres que Antígona ousa conceder a seu irmão, em seu ato transgressor, constituem o signo capaz de distingui-lo de um animal, o gesto capaz de humanizá-lo e eternizá-lo na memória da família. A segunda morte é o que se trata de evitar — é a morte do simbólico. Para tanto, contudo, é preciso consentir na própria morte. Para evitar a segunda morte, Antígona conta com seu fim inevitável.

Há ainda a apropriação do conceito freudiano de pulsão de morte e a influência da filosofia heideggeriana que propaga os limites do ser como ser-para-amorte. Trata-se, novamente, de destacar a barreira que se impõe à ordem simbólica e, nos percalços da solução trágica, de enfatizar um ponto que não admite qualquer conciliação.

Antígona é tomada como a expressão mais autêntica de uma postura conseqüente, que mantém o estreito vínculo entre o desejo e a morte, a ponto de figurar como representante de um "puro desejo de morte” (LACAN, 1960/ 1991, p.342).

Eis o ponto de impasse a que nos conduz a vertente trágica do desejo, passível de receber, a nosso ver, um outro tratamento, por meio de uma investigação acerca da comédia.

O que seria, com efeito, um desejo puro, exilado de toda possibilidade de enlaçamento com a comunidade discursiva que, afinal, sempre lhe impingirá uma quota necessária de sacrifício? Que desenlace para o desejo, quando esse sacrifício não se traduz pela vertente absoluta da morte?

Cabe precisar, sobre esse aspecto, que não encontramos, em momento algum, ao longo do comentário de Lacan, uma associação literal entre o preceito ético de não ceder sobre o desejo, preconizado pela psicanálise - do qual, afinal Antígona é o representante legítimo - e o ato suicida da perso-

\footnotetext{
${ }^{4}$ Trata-se de uma passagem de O sistema do papa Pio VI, em que Sade elabora uma teoria do crime, argumentando que o assassino tira apenas a primeira vida de sua vítima, restando o desafio do aniquilamento que concerne à eliminação de uma segunda vida (Cf. LACAN, 1998, p.257-258).
} 
nagem. ${ }^{5}$ Em outras palavras, nada nos autoriza a identificar o puro desejo de morte a uma procura objetiva pela morte. Lacan é explícito, ao definir o desejo do analista como um desejo prevenido. Prevenido, devemos concluir, quanto à precariedade da resposta do Outro e ao desamparo reafirmado nessa constatação. Mas o analista — prossegue Lacan — não pode desejar o impossível (LACAN, 1960/1991, p.360). Essa é, aliás, a advertência de Ismene ao tomar conhecimento da decisão de sua irmã (SÓFOCLES, 1999, p.32).

Em contrapartida ao que se anuncia na perspectiva trágica como sendo o "triunfo da morte" (Idem, p.376) — compreendida como a expressão maior da dimensão trágica da subjetividade, do ponto abissal em que se lança o homem marcado pelo significante - Lacan introduz alguns aspectos relativos à vertente do cômico. Esclarece tratar-se, aí também, “da relação da ação com o desejo, e de seu fracasso fundamental em alcançá-lo” (Idem). É curioso destacar que o enquadre proposto por Lacan para introduzir a comédia seja o mesmo proposto para a análise do trágico, a saber, o desejo e os limites de sua realização. Do lado da Comédia podemos extrair, portanto, uma posição que também toca a questão ética. Na seqüência, lemos:

“o que nos satisfaz na comédia, nos faz rir, nos faz apreciá-la em sua dimensão humana, não excetuando o inconsciente, não é tanto o triunfo da vida quanto sua escapada, o fato de a vida escorregar, furtar-se, fugir, escapar a tudo o que lhe é oposto como barreira, e precisamente as mais essenciais, as que são constituídas pela instância do significante”. (LACAN, 1960/1991, p.376)

A comédia entra em destaque, precisamente por sua "dimensão humana”. Humana, talvez, em oposição ao que se apresenta como o aspecto desumano da personagem Antígona, cujo ato de forçar em direção a uma escolha absoluta conduz necessariamente ao dilaceramento. Se a tragédia traduz algo relativo ao que não se deixa civilizar/simbolizar no homem, algo como um limite só transposto mediante o sacrifício do ser, a comédia parece fornecer uma via original de transposição desse limite do insuportável dado pelo significante enquanto barreira. E essa operação aponta não para o triunfo da vida -

\footnotetext{
${ }^{5}$ Morel apresenta-nos um comentário interessante a respeito dessa configuração do puro desejo de morte, tal como surge no Seminário VII de Lacan. Antígona seria, segundo as palavras da autora, a encarnação do desejo criminoso da mãe (Jocasta) enquanto um desejo não mediado pela função paterna e que, por conseqüência, não acede a uma versão simbólica, o que propicia um encontro fatídico com o real. Isso não significa que ela deseje, propriamente, a morte (Cf. MOREL, 1999, p.14).
} 
esboçado, imaginariamente numa celebração ${ }^{6}$ que promoveria o bem-estar a despeito dos efeitos desse insuportável — mas pelo índice de sua escapada, por entre as gretas da barreira significante.

O triunfo da morte é então balizado pela escapada da vida, em relação ao que se impõe como barreira significante. O termo "vida” é muito vago e não tem um estatuto conceitual. Talvez pudesse ser substituído pelo conceito de gozo, ainda não muito explorado, por ocasião do seminário da Ética, mas que guarda, como teremos oportunidade de conferir, uma conexão estreita com a abordagem lacaniana da comédia.

O gozo é um conceito que mantém uma certa vizinhança com o de das Ding, e denota, em linhas gerais, a vertente pulsional do psiquismo que visa a satisfação pura e simples, apenas manifesta, contudo, como efeito de uma operação fracassada no que tange o circuito de investimentos do desejo, sempre marcados pelo recalcamento. Daí o caráter exigente da pulsão, que denuncia um déficit de satisfação e quer sempre um pouco mais.

Se a tragédia situara-se como a expressão da relação de fatalidade que o homem mantém com a fala, a comédia apontaria para um tipo diferente de relação em que algum proveito pode ser daí extraído. Uma relação de consumo com a palavra, diz-nos Lacan, em que se torna possível gozar da palavra. Não temos mais o homem engajado no conflito insolúvel, mas aquele capaz de usufruir a palavra em sua materialidade (LACAN, 1958/1999, p.273).

No seminário que trata das formações do inconsciente, Lacan convida seus ouvintes a lerem comédias para que apreendam a relação possível entre o inconsciente e o domínio do cômico. Esclarece, de saída, que a comédia não é o cômica.

Freud havia definido o cômico, em Os chistes e sua relação com o inconsciente como uma mera constatação de uma cena risível, um fenômeno bruto de riso, que depende apenas de dois atores, um que é objeto de riso e outro que constata e acusa o efeito cômico (FREUD, 1905/1969, p.207). Os chistes, por sua vez, implicariam um trabalho refinado no plano lingüístico e requereriam a presença de uma terceira pessoa que os avalizassem enquanto manobra significante, equívoco, mal-entendido.

\footnotetext{
${ }^{6}$ A origem da comédia está ligada, como expressa o termo grego Komoidía, à festa, à dança, à alegria. O casamento é um desfecho recorrente em muitas das comédias aristofânicas, em geral regado a muito vinho e descontração. O banquete cerimonial, que constitui uma das fontes originárias da comédia, é visto por Lacan como um retorno ao gozo mais elementar. A comédia termina, é certo, em união em contraste com a tragédia, que expressa, em geral, a separação. O que estaria na base desse espírito da comunhão, contudo, não parece ser, aos olhos de Lacan, uma saída ilusória, imaginária que encobre o mal-estar, mas um retorno do gozo, uma nova edição do gozo que sobrevém ao fim do percurso do herói (LACAN, 1999, p.140).
} 
Entendamos, provisoriamente, a afirmação de Lacan como uma maneira de apreender a comédia para além dessa definição restrita do cômico, proposta por Freud.

O exemplo de As nuvens, de Aristófanes, é evocado pelo autor na tentativa de elucidação da maneira pela qual “o isso se apodera da linguagem” (LACAN, 1958/ 1999, p.139), ou de como se articulam, na comédia, o gozo e o significante.

Passemos à peça. Um velho fazendeiro encontra-se depauperado e endividado, em função da prodigalidade do filho fanático por cavalos e carros. Resolve recorrer a Sócrates, o filósofo, famoso por seus sofismas capazes de reverter qualquer realidade por meio de manobras engenhosas. Strepsíades o procura, na esperança de aprender a arte da persuasão e, assim, enganar seus credores, livrando-se das dívidas. Idoso e com o espírito embrutecido, não consegue captar qualquer ensinamento, indo o filho, Fidípides, aprender em seu lugar. Segue-se um debate entre o Raciocínio Justo e o Injusto, saindo o segundo vencedor. Com a ajuda dos ensinamentos socráticos transmitidos ao filho, Strepsíades consegue livrar-se dos credores, mas torna-se vítima de sua agressividade, pois o jovem, por meio dos mesmos ensinamentos, prova-lhe ser justo espancar o pai.

Lacan faz-nos notar a habilidade de Aristófanes em transformar a bela dialética socrática em instrumento do gozo particular de um velho esperto e desonesto. As necessidades mais básicas, do sexo, da ganância, da irreverência são atingidas por meio desse artifício (LACAN, 1958/1999).

A dialética socrática, apresentada por Platão como sendo o exercício racional que garante as vias de acesso ao conhecimento de uma verdade sobre o ser, converte-se, na peça de Aristófanes, no "pensatório”, lugar a que se dirigem os iniciados que passarão por um "moinho de palavras” (ARISTÓFANES, 1995) a fim de tornarem-se mestres na arte do engano, da infâmia, da difamação. Uma mestria às avessas, uma vez que faz deslizar o eixo em torno do qual consolidase o nexo do discurso racional para o registro do absurdo e do nonsense.

O Sócrates da peça de Aristófanes representa tudo o que se podia depreender de pior das correntes iluministas que invadiam a nova geração do homem grego, trazendo conseqüências desastrosas para os diversos setores da vida pública, em especial para a esfera política. A comédia só adquiriu sua importância e reconhecimento, esclarece-nos Jaeger, quando passou a fazer parte da vida pública e do debate político ateniense, donde sua função específica na formação do espírito do homem grego (JAEGER, 1995). A tensão entre os princípios e valores antigos e os novos está no centro de As nuvens e materializa-se na cena do debate entre o logos Justo e o logos Injusto. Esta passagem é comparada ao debate entre Ésquilo (passado) e Eurípedes (atualidade), na peça As rãs. 
Se a comédia pode habitar o domínio do nonsense e do absurdo, sem deixar de afirmar-se como um meio de fomentar a crítica e a reflexão do público, ou seja, de propiciar a transmissão de uma verdade submetida à censura, isto se dá através da suspensão de uma barreira, de uma sanção que autoriza o tratamento do que é mais sublime e respeitável pelo viés da abjeção e da derrisão. Tudo isto com que finalidade? Fazer rir ou deixar passar um ganho de prazer.

Talvez possamos compreender o interesse de Lacan pelo dispositivo cômico por tratar-se de um artifício que propicia uma vazão para o gozo, que não se deixa circunscrever em nenhuma forma de discurso, de uma forma inédita e surpreendente. Temos então essa condensação original da "bela dialética socrática” com a pior espécie de exercício sofístico, como um meio, uma maneira original de fazer passar um gozo que se alia a um efeito de verdade. A possibilidade de se transpor uma barreira, por meio da provocação de uma ruptura com o que se anuncia como as mais seguras e estáveis configurações discursivas (política, filosofia) é uma oportunidade promovida pelo estilo cômico que não se verifica na tragédia, pois, se aí assistimos à assunção de um sujeito em posição de exceção frente à determinação simbólica que o cerca, isto se dá apenas ao preço do total isolamento da comunidade discursiva. ${ }^{7}$

Em estudo consagrado à natureza paradoxal do herói grego desde Homero (Ilíada) até os expoentes maiores do teatro clássico, como Sófocles, Eurípedes e Aristófanes, Cedric Whitman dedica-se a mostrar, com muita originalidade, até que ponto também as peripécias do herói cômico revelam, de modo agudo, seu isolamento. O autor convida-nos a escutar no teatro de Aristófanes — para além das performances satíricas e paródicas que, por meio de estratégias tradicionais do gênero cômico, exaltam, tão simplesmente, o ridículo - “a voz do espírito do isolamento” (WHITMAN, 1982, p.136), audível afinal, com extrema nitidez, nos heróis saídos das tragédias sofoclianas.

O autor empenha-se em ressaltar o vínculo estreito existente entre as perspectivas trágica e cômica, conferindo destaque especial a uma peça concebida nos primórdios da carreira literária de Aristófanes, Os arcanenses.

Esta peça apresenta-nos o personagem Diceópolis (em grego, cidadão reto) tomado de indignação pelas conseqüências nefastas trazidas pela guerra. A primeira cena estampa um cidadão solitário em dia de assembléia do povo. Aos poucos, vão chegando os participantes, inicia-se o debate e o herói é silenciado

\footnotetext{
${ }^{7}$ Não é essa uma estrutura muito próxima da que se verifica no processo dos chistes? A supressão de barreiras, a presença do fator surpresa, a recuperação de prazer e a transmissão de uma verdade inconsciente não são todas características caras ao procedimento espirituoso? Ainda que o gênero cômico inscreva-se em um plano diverso, poder-se-ia conceber a comédia, sob determinados aspectos, como portadora da estrutura de um chiste? Eis uma hipótese a ser lançada com cautela e que podemos deixar reservada para maiores desdobramentos.
} 
a cada vez que tenta manifestar-se em favor da paz. Ao sustentar uma posição inconcebível pelos demais, ou seja, a de concretizar as tréguas com o inimigo abominável, Diceópolis constata, a cada nova investida, a inoperância de sua palavra. Persistente, contudo, decide agir. Resolve negociar isoladamente a paz, obtendo uma trégua particular que o contemple e à sua família, exclusivamente. A intriga prossegue em diversos desdobramentos que não cabe esmiuçar aqui mas que aos poucos leva o mercado do herói, regado pela fartura e abundância trazidas pela trégua, a uma enorme popularidade.

Ali, como em Antígona, observa-nos Cedric, o herói insurge-se contra a ordem política estabelecida por meio de um gesto único, singular e, sobretudo, eficaz (no caso da comédia) pois, ao fim, todos se interessam pelas benesses advindas de sua negociação particular (o mercado farto e abundante que contrasta com a miséria da guerra). Para além da mensagem óbvia do pacifismo moralizador (o bem de todos) - em geral interpretado como sendo a principal contribuição dessa peça — , convém destacar, como Cedric, o paradoxo mesmo do isolamento daquele que, para enunciar uma verdade por todos recusada, deve agir sozinho contra o senso comum, mas também (e ao mesmo tempo) em favor da ética na cidade. O cidadão justo está só e age por conta própria, a despeito do que possa vigorar como consenso político ordenador das relações humanas no plano da cidade. O que o teatro grego clássico nos transmite - seja na sua versão trágica seja pela vertente da comédia - é um modo de resposta para a fissura existente entre o individual e as estruturas sociopolíticas em que ele se inscreve (WHITMAN, 1982, p.41).

Se for possível detectar um ponto de convergência entre a postura ética do herói trágico em relação à do herói cômico - a saber, o gesto obstinado que a ambos faz persistir na busca por um desejo que constitui o estofo de uma resposta subjetiva e singular — , resta-nos perguntar em que ponto começa o traçado de sua divergência. Do lado da comédia, opera-se com maior liberdade em relação ao gozo, cujo conceito remete-nos tanto para a vertente da morte e da perda, quanto para o aspecto da vida, da exigência pulsional propriamente dita. É notável como os heróis cômicos escapam vivos ao final de um percurso sempre tumultuado.

A comédia veicula um poder restaurador de forjar uma nova saída, uma saída inédita para o sujeito em relação à sociedade, que não está presente na vertente trágica. Vale retomar o texto de Cedric no ponto em que ressalta uma interessante estratégia, presente em algumas passagens do teatro de Aristófanes. Trata-se da operação transformadora dos objetos, símbolos da mais profunda alienação política. Com efeito, ao final de Paz, vemos os antigos acessórios da guerra, caídos então em desuso após o advento da paz, adquirirem nova finalidade. Um capacete pode converter-se em taça de vinho, assim como uma lança pode ser usada como 
estaca na lavoura. Os objetos dão lugar a um novo uso, graças ao poder transformador da arte cômica (WHITMAN, 1982, p.141). Um novo uso, nem sempre nobre, como indica o exemplo que o autor se abstém de fornecer-nos: uma couraça que se transmuta em penico... (ARISTÓFANES, 1969, p.122).

Freud, em um pequeno artigo de 1908, interessa-se por saber de que modo as produções poéticas nos tocam de forma tão peculiar, despertando-nos as mais intensas emoções. Observa que o devaneio comum ou a fantasia neurótica de cada um são, no mais das vezes, ocultos por seu autor e, se fossem relatadas, não causariam o menor deleite e sim o mais sincero repúdio. Segundo o autor:

“A verdadeira ars poetica está na técnica de superar esse nosso sentimento de repulsa, sem dúvida ligado às barreiras que separam cada ego dos demais. (...) O escritor suaviza o caráter de seus devaneios egoístas por meio de alterações e disfarces e nos suborna com um prazer puramente formal (...) Denominamos de prêmio de estímulo ou de prazer preliminar ao prazer desse gênero, que nos é oferecido para possibilitar a liberação de um prazer ainda maior, proveniente de fontes psíquicas mais profundas."8 (FREUD, 1908/1976, p.158)

Esta passagem parece-nos sugestiva — ainda que Freud não se refira, especificamente, à comédia ou a qualquer outro gênero literário em particular por aliar a atividade poética ou imaginativa a essa idéia do suborno (Bestechen) de prazer. A idéia de uma ação ilícita, marginal, extravagante e, ao mesmo tempo engenhosa, que obtém êxito por meio do disfarce estético (ou de um uso original da linguagem) com vistas a um prêmio de estímulo (Lustgewinn) parece-nos ilustrativa no que diz respeito às hipóteses que julgamos possíveis sustentar.

Do ponto de vista da tragédia, o Outro parece não ser subornável com uma cota a mais de prazer, um resto de gozo, pois veicula uma lei implacável, regida pela lógica da exclusão (ou...ou). Ao final do diálogo com sua irmã Ismene, Antígona revela ser muito alto o preço a pagar, caso resolvesse abrir mão de sua decisão: "deixe-nos então, eu e minha loucura, submetermo-nos a esta terrível prova. Eu não me submeteria a nada que pudesse me privar de uma morte gloriosa" (SÓFOCLES, 1999, p.18). De um lado, a submissão (morte do sujeito e do desejo), de outro, a honra (o desejo), cuja condição é a morte. Na tragédia, estamos no plano de uma escolha radical, que parece levar, de qualquer

\footnotetext{
${ }^{8}$ A expressão "prazer preliminar" está presente no estudo sobre os chistes, em que Freud observa os efeitos da supressão das inibições neles presente. Um ganho de prazer muito maior do que o que seria possível obter em determinadas circunstâncias sobrevém nos moldes da tirada espirituosa, sob a forma de um "princípio de colaboração" (FREUD, 1905/1969, p.160).
} 
maneira, ao encontro do pior: seja qual for a escolha, arca-se sempre com um custo extremo e irreversível, cuja imagem mais comum é a morte.

A comédia lança mão de uma estratégia que, por estabelecer um novo tipo de relação com a linguagem, permite um tratamento, igualmente novo para o desejo e as formas do ideal que lhe pretendem fixar uma tradução. Qual seria então a novidade proporcionada pela via aberta na comédia, uma vez que ambas tratam o desejo na sua articulação com a falta (ou com o fracasso de sua realização) de acordo com Lacan? Os personagens saídos do teatro de Aristófanes apresentam-se, por vezes, como tivemos oportunidade de mostrar, como seres em franco desamparo, tal como os protagonistas do teatro trágico de Sófocles. Afinal, esse isolamento - que pode ser compreendido como um ponto de falta no campo do Outro, ou ainda um modo particular de gozo que sinaliza a divisão subjetiva - encontra uma versão possível no plano coletivo, um modo de inscrição capaz de assegurar a subsistência do sujeito marcado por sua divisão. Esse elemento de amarração, de atrelamento do desejo ao gozo é o que falta na perspectiva trágica, em que o sujeito é sempre relançado ao limite entre o significante e a coisa de modo a certificar-se da impossibilidade desse encontro ou do que ele contém de catastrófico.

Tal estratégia não visa à reconciliação fácil e banal, muitas vezes sugerida por uma visão catártica do riso que traz alívio e leva ao esquecimento, mas permite operar com a transmissão de uma verdade sobre o desejo e o gozo. Uma transmissão, enfim, que preserva o laço social, tornando-o sensível a um novo dizer que transpõe os arremates do dito e conjuga, afinal, os efeitos disruptivos do desejo a uma certa ordem discursiva.

Digamos para concluir que, se a psicanálise pôde contribuir para manter vivo o interesse contemporâneo sobre do teatro antigo, sem amortecer seus efeitos de questionamento e transgressão — de modo inverso do que se pode depreender em algumas das leituras filosóficas relativas ao tema do trágico é possível detectar, levando-se em conta o conjunto da obra de Lacan, que essa contribuição não se restringe à famosa passagem do seminário da Ética, dedicada à leitura da peça Antígona. Além disso, poderíamos suspeitar de que o paradigma ético adotado pelo autor nos anos $1960,{ }^{9}$ não esgota os problemas éticos da psicanálise, sobretudo aqueles suscitados a partir das formulações finais da obra de Lacan, em que o sujeito não é mais convidado a situar seu desejo na encruzilhada do significante e da coisa, ou seja, no limite de sua depuração, mas é levado a coabitar o universo da coisa, encontrando novas formas de lidar com seu sintoma.

\footnotetext{
${ }^{9}$ O paradigma ético proposto por Lacan nos anos 1960 poderia ser expresso em termos da prerrogativa de não ceder em relação ao desejo, tão bem retratado na intriga de Antígona.
} 
Acreditamos que a leitura das comédias de Aristófanes pode tornar-se um instrumento interessante para a apreensão das questões éticas em psicanálise, pois seus personagens confrontam-se, freqüentemente, com situações limite, que implicam um posicionamento e uma escolha, de tal forma que o sujeito seja ele bom ou mau e, de fato o teatro grego arrasta-nos para fora desses parâmetros fixos - deve impor-se contra o consenso geral, que pretende legiferar o conjunto de práticas políticas e sociais, sempre tão complexas e intrinsecamente contraditórias, em nome de um suposto bem de todos. Além de retratar tão bem o estatuto ético do sujeito que age por meio de sua singularidade, o teatro de Aristófanes ensina-os algo mais. Recheia a tal singularidade de seus personagens com ingredientes da mais pura híbris: egoísmo, perversidade, insensatez, luxúria, colocando-os em total desagregação com as exigências da cultura, para torná-los, contudo, hábeis no trato com esses elementos imponderáveis, imprevistos do ponto de vista da ordem pública. Essa conjunção do particular ao universal não se dá pela adaptação de campo ao outro, pois nesse caso temos o desvanescimento do sujeito, mas suporta uma disjunção fundamental que não anula a tensão entre as partes. 


\section{REFERÊNCIAS}

ARISTÓFANES. As nuvens (1995) Tradução Mário da Gama Kury. Rio de Janeiro: Jorge Zahar Editor. Os arcanenses (1980) Tradução Maria de Fátima de Souza e Silva.

Coimbra: Instituto de Investigação Científica/ Universidade de Coimbra.

A paz (1969) Tradução Mário da Gama Kury. Rio de Janeiro: Edições de Ouro, 1969

BRANDÃO, J. S. (1999) Teatro grego. Petrópolis: Vozes.

DODDS, E.R. (1988) Os gregos e o irracional. Lisboa: Gradiva.

FREUD, S. (1969) Edições standard brasileira das obras psicológicas completas. Rio de Janeiro: Imago.

(1905/1976) "Os chistes e sua relação com o inconsciente”, v.VIII, p.13.

(1895/1976a) "Projeto para uma psicologia científica”, v. I, p.395.

(1908/1976) "Escritores criativos e devaneios", v. IX, p. 149.

JAEGER, W. (1995) Paidéia. A formação do homem grego. São Paulo: Martins Fontes.

LACAN, J. (1958/1999) O Seminário, livro 5, As formações do inconsciente. Rio de Janeiro: Jorge Zahar Editor.

. (1960/1991) O seminário, livro 7, A ética da psicanálise. Rio de Janeiro: Jorge Zahar Editor.

(1958/1998) "De uma questão preliminar a todo tratamento possível da psicose”, in Escritos, Rio de Janeiro: Jorge Zahar Editor.

MOREL, G. (1999) Lectures d'Antigone, in Carnets de Lille n. 5. Paris: Institut du Champ Freudien.

NIETZSCHE, F. (1872/1992) O nascimento da tragédia. São Paulo: Cia das Letras.

ROSENFIELD, K. (2000) "Entre o tédio e o suspense", in Folha de S. Paulo, Caderno Mais!, 4 de junho.

SÓFOCLES. (1999) Antigone.Trad. Jean \& Mayotte Bollack. Paris: Les Éditions de Minuit.

STEINER, G. (1995) Antígonas. Lisboa: Relógio D’água.

TAMINIAUX, J. (1995) Le théatre des philosophes. Grenoble: Jérome Millon. VERNANT, J. -P. \& VIDAL-NAQUET, P. (1988) Mito e tragédia na Grécia antiga. São Paulo: Brasiliense, cap. 2.

WHITMAN, C. (1982) The heroic paradox, London, Cornell University Press.

Laura Lustosa Rubião

Rua Eng. Amaro Lanari 378/701 Sion

30310-580 Belo Horizonte MG

llrubiao@terra.com.br 